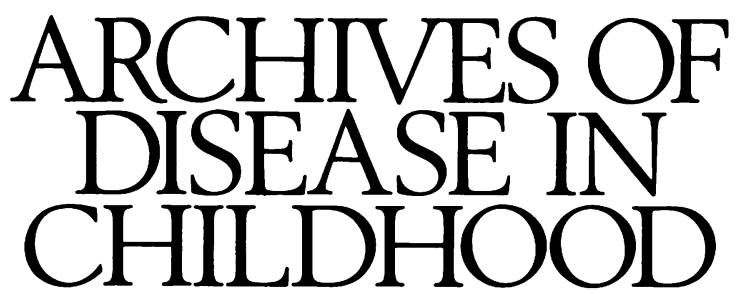

The Fournal of the British Paediatric Association

\title{
Welcome to a new editor
}

This month we welcome Dr Harvey Marcovitch to his appointment as joint editor of the Archives. He is currently Consultant Paediatrician and Clinical Director of Paediatrics at Horton General Hospital, Banbury, and Clinical Lecturer at the University of Oxford. $\mathrm{He}$ is Chairman of the Medical Advisory Council of Oxford Regional Health Authority, and a member of its Postgraduate Medical Education and Training Committee.

He has a special interest in medical education particularly at the interface of general practice and hospital paediatrics. $\mathrm{He}$ is a skilled medical author having written numerous informative articles on basic paediatric problems in medical magazines and scientific journals, as well as chapters in textbooks.

Harvey Marcovitch is experienced in medical journalism, having been one of our associate editors since 1990 . His promotion will help maintain the high standard of the journal.

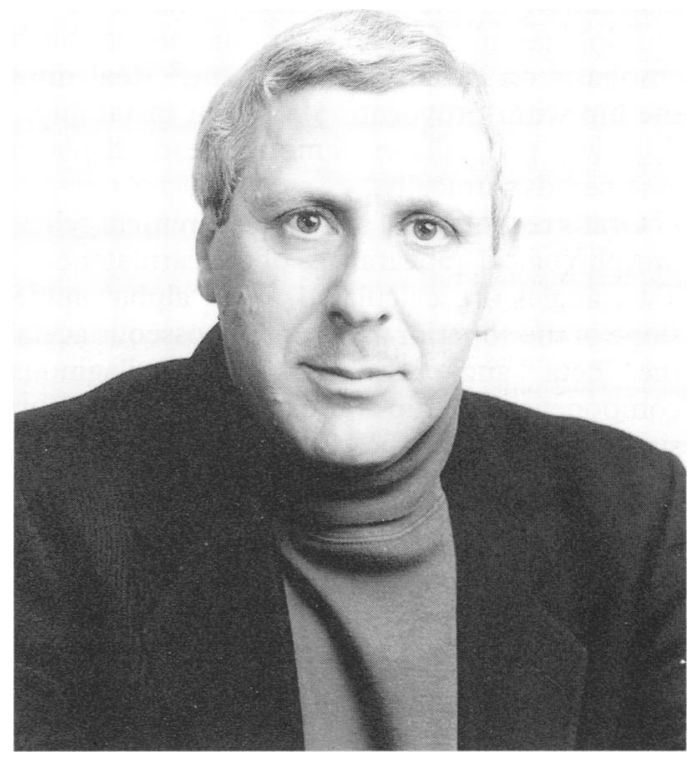

Editors of the Archives:

Hugh Thursfield and Reginald Miller

1926-33

Charles Harris and Alan Moncrieff

1934-38

Alan Moncrieff and Richard Ellis

$1939-45$

Richard Ellis

1946-47

Richard Ellis and Philip Evans

$1948-49$

Philip Evans and Ian Cathie

$1950-54$

Ian Cathie and Richard Dobbs

$1954-63$

Richard Dobbs and Douglas Gairdner

1964-69

Douglas Gairdner and Roger Robinson

1969-79

Roger Robinson and Roy Meadow

1979-82

Roy Meadow and Bernard Valman

1982-87

Bernard Valman and Malcolm Chiswick

1987-94

Malcolm Chiswick and Harvey Marcovitch

$1994-$

MALCOLM CHISWICK 